\title{
Isolation of biosurfactant producing bacteria from petroleum contaminated sites and their characterization
}

\author{
Rida Batool, Samra Ayub and Iqra Akbar \\ Department of Microbiology and Molecular Genetics, University of the Punjab, Quaid-e-Azam Campus, Lahore
}

\begin{abstract}
Biosurfactants are microbial amphiphilic compounds which can reduce surface tension between aqueous and hydrocarbon mixtures. Bacterial strains isolated from petroleum contaminated soil of various motor workshops were characterized morphologically and biochemically. Biosurfactant producing ability of the strains was determined and their emulsification activity was screened against different oils. All the selected bacterial strains showed enhanced biosurfactants production with yeast extract as nitrogen source and glucose as carbon source at optimized conditions. These strains also exhibited multiple metal and antibiotics resistance. Isolated biosurfactants of three most promising strains SF-1, SF-4 and SM-1 were extracted by solvent extraction and subjected to TLC technique. The technique indicates the glycolipid nature of the compounds and presence of rhamnose sugar, which was further confirmed by FT-IR analysis. 16srRNA analysis revealed that SF-1 and SM-1 had close resemblance with Pseudomonas sp. while SF-4 showed homology with Enterobacter sp. Isolation and screening of biosurfactant producing strains from petroleum polluted places proved to be a quick and effective means to find bacterial strains with possible industrial uses.
\end{abstract}

Keywords: Biosurfactant, TLC, FT-IR, 16s rRNA sequencing, heavy metals.

\section{Introduction}

In today's world, petroleum usage has increased to the exponential level and contaminating the environment very badly. Since 1970, more than 5 million tons of oil spills are reported by International Tanker Owners Pollution Federation affecting serious health problems. Petroleum oil is a non-volatile and low molecular compound (Budsabun, 2015). Biosurfactants are surface active compounds produced by different bacteria. These compounds are involved in reducing the surface tension of organic and non-organic mixtures. They make interfaces among various solution depending upon their polarities such as oil and water resulting in lowering the interfacial tension (ElSheshtawy, et al., 2015). Bio-surfactants are compounds mostly used because they are environment friendly, easily degraded, low toxicity and produced from cheaper substrates (Meybodi, et al., 2013). These compounds have displayed promising surface activity (Hassanshahian, 2014). They are classified into various groups such as glycolipids, lipopeptides, polysaccharide-protein complexes, phospholipids, fatty acids and neutral lipids etc. (Hassanshahian, 2014).

Glycolipids and lipopeptides are low molecular weight surfactants (Ron and Rosenberg, 2001). Glycolipids are further characterized into three subgroups i.e. rhamnolipids, trehalolipids and sophorolipids. Different bacteria are reported to produce biosurfactants including surfactin by Bacillus subtilis and the rhamnolipids from Pseudomonas aeruginosa (Batista et al., 2006). Different species of Bacillus are reported to produce surfactin and lichenysin such as $B$. coagulans, B. pumilus and B. licheniformis (Ongena et al., 2008). They are involved in the biodegradation of hydrocarbons, augmentation of oil recovery and elimination of metals from a contaminated soil. A group of biosurfactants known as polymeric biosurfactants such as emulsion, alaskan, biodispersan, liposan and mannoproteins etc. They are usually produced by Acinetobacter and some species of yeast. Biosurfactants have exhibited antimicrobial activity (Maier, 2003). Some biosurfactants acts as antimicrobial and therapeutic agents (Rodrigues et al., 2006). Some studies showed that rhamnolipid produced by strains possess certain antibacterial and antifungal activities (Cameotra and Makkar, 2004). Biosurfactants play a significant part in the remediation of certain heavy metals as they form complexes with metals via strong bonds in soil as compared to binding of metal to the soil. This process can be helpful in the management of waste water contaminated with heavy metals (Das et al., 2009). Promising applications of biosurfactants is to improve oil recovery and to develop methods for the extractions of lingering oil which situated in the sections of the

*Email: rida.mmg@pu.edu.pk

(C) 2017, Soil Science Society of Pakistan (http://www.sss-pakistan.org) 
reservoir which are distant and the oil is imprisoned in the holes by duct pressure (Sen, 2008). Researchers suggest that rhamnolipid is capable of reducing metal toxicity to microbial associations in co-contaminated soils by the combination of metal complexation and in the amendment of cell surface properties through the release of LPS resulting in boosted bioremediation (Sandrin et al., 2000). The current research was designed to isolate biosurfactants producing bacteria from petroleum polluted soil. Because of their diversity, biosurfactants are considered as an attractive group of compounds for their widespread use in various industrial and biotechnological processes.

\section{Materials and Methods}

\section{Isolation of bacteria}

Greasy soil samples from various service stations located in the vicinity of Punjab University, Lahore were collected in sterilized bottles. To isolate the biosurfactant producing microorganism, one gram of soil sample was inoculated in $100 \mathrm{ml}$ of mineral salt media (Patil et al., 2012) containing 1 to 5\% diesel, petrol and Mobil oil instead of glucose as carbon source. After 1 week of incubation on shaker, $50 \mu \mathrm{l}$ of subculture was taken and then transferred into fresh medium in flasks and was incubated under same conditions. In order to enrich the microbial cultures and to increase the population density, this procedure was repeated thrice. After this, $50 \mu \mathrm{l}$ of culture was taken and spreaded on MSM agar plate to isolate biosurfactant producing microorganisms. These plates were incubated at $37{ }^{\circ} \mathrm{C}$ for $4-5$ days (Ahmed et al., 2016). Different colonies appeared on agar plate were observed and selected for further purification.

\section{Qualitative screening}

Hemolysis as an indication of biosurfactants production was observed on Blood agar media. This test provides information about what kind of hemolytic enzyme a bacterium possesses (Bicca et al., 1999). Colonies showing hemolysis were tested further by oil spread technique. Oil spread technique is very useful as it can be employed when the activity and quantity of biosurfactants is low. For this purpose, $100 \mu 1$ of crude oil was added on the surface of $50 \mathrm{ml}$ of distilled water followed by the addition of $10 \mu \mathrm{l}$ of bacterial culture. A plaque on oil surface indicates biosurfactants activity of the culture. The drop collapse and CTAB blue agar plate method was carried out as described by Bodour et al., 1998; Siegmund and Wagner, 1991, respectively. Drop collapse assay is a very simple assay for screening of biosurfactant producing bacteria while CTAB assay indicates the production of anionic surfactants.

\section{Quantitative screening}

Isolates that exhibited positive results in qualitative assay were subjected to quantitative assay and their emulsification index was determined (Shoeb et al., 2015).

\section{Morphological and biochemical characterization of selected strains}

Selected isolates were observed for colony morphology, Gram's nature, capsule staining, spore formation and motility. Biochemical nature of selected isolates was characterized by catalase, oxidase, citrate, indole, sugar fermentation and nitrate reduction (Cappuccino and Sherman, 2002).

\section{Optimization of growth parameters for the production of biosurfactants}

Different carbon (glucose, sucrose, fructose, and glycerol) and nitrogen sources (yeast extract, beef extract, ammonium chloride, and potassium nitrate) were examined in order to know the best combination of nutrients for biosurfactant production using MSM as a basal media. To optimize conditions for maximum biosurfactant fabrication, strains were grown at a wide range of temperature $(27,37$, 45 and $50^{\circ} \mathrm{C}$ ) and $\mathrm{pH}$ (3-9). Each factor was changed accordingly by keeping rest of the other constant.

\section{Biosurfactant production in different oils}

Activity of biosurfactant producing strains was checked in different oils like gangrene, coconut, sunflower, kerosene and olive oil. After 24 hours, the height of stable emulsion layer is measured by calculating emulsification index (Copper and Goldenberg, 1987).

\section{Antibiotic and metal resistance profiling}

Antibiotic resistance profiling was done to determine the susceptibility of bacteria against various antibiotics (Ampicillin, Tetracycline, Streptomycin, Chloramphenicol, Kanamycin and Erythromycin) at different concentrations by plate dilution method. Similarly, to check metal tolerance profile of biosurfactant producing strains, 5\% stock solution of cobalt nitrate $\left(\mathrm{Co}\left(\mathrm{NO}_{3}\right)_{2} \cdot 6 \mathrm{H}_{2} \mathrm{O}\right)$, Cadmium chloride $\left(\mathrm{CdCl}_{2} \cdot \mathrm{H}_{2} \mathrm{O}\right)$, Copper sulfate $\left(\mathrm{CuSO}_{4}\right)$, and Zinc sulfate $\left(\mathrm{ZnSO}_{4} .7 \mathrm{H}_{2} \mathrm{O}\right)$ were prepared and nutrient agar plates were supplemented with respective metal stock solution. MIC of each heavy metal was determined by plate dilution method. Appearance of growth on metal / antibiotic supplemented plate indicated the positive result for resistance.

\section{Solvent extraction of crude biosurfactants}

Solvent extraction was performed for the isolation of crude biosurfactants. Bacteria were cultured in MSM broth for 
48 hours on a shaker at $100 \mathrm{rpm}$ at $37^{\circ} \mathrm{C}$, centrifuged at 10,000 rpm for 20 minutes under cooling conditions. Supernatant was taken and concentrated $\mathrm{HCl}$ was added to adjust the $\mathrm{pH}$ at 2.0 and left it overnight at $4^{\circ} \mathrm{C}$. Next day, centrifuged the acidified supernatant at $10,000 \mathrm{rpm}$ for 20 minutes at $4^{\circ} \mathrm{C}$ and grey white precipitate was collected for further extraction of biosurfactant compounds. Ten milliliters of chloroform and methanol in the ratio $(2: 1 \mathrm{v} / \mathrm{v})$ were added in order to precipitate the pellet and incubated at $30^{\circ} \mathrm{C}$ for 15 minutes. The content was centrifuged for $20 \mathrm{~min}$ under cooling conditions and supernatant was evaporated by air drying. The residue was dispensed in sodium phosphate buffer ( $\mathrm{pH} 7.0)$ and stored at $4^{\circ} \mathrm{C}$.

\section{Purification of biosurfactants}

Chloroform was used to dissolve the crude extracts and then analyzed by thin layer chromatography (TLC). About $10 \mu 1$ of crude extract was placed on silica gel plate at a 2 $\mathrm{cm}$ above from the bottom of the plate. Tween-80 was taken as a control. Plate was dried, and developed in a solvent system of chloroform: methanol in the ratio 95:5. After developing, plate was taken out and allowed to air dry. Developed plate was observed under UV at longer and shorter wavelength and stained it with iodine fumes. Yellow colored spots were observed.

\section{FT-IR analysis}

FTIR (Fourier Transform Infra-red Spectroscopy) is a sensitive and primarily technique for identifying the functional groups present in the sample. $\mathrm{KBr}$ pellet of crude extracts were made and the frequency range is measured as wave numbers $4000-500 \mathrm{~cm}^{-1}$.

\section{6srRNA sequencing of most promising strains}

For 16S rRNA sequencing, bacterial strains were sent to Macrogen Inc, Seoul, Korea for 16S rRNA gene sequencing. $16 \mathrm{~S}$ rRNA sequence was determined using primers $518 \mathrm{~F}$ (CCAGCAGCCGCGGTAATACG) and 800F (TACCAGGGTATCTAATCC). Reverse complementary sequence was made by reverse primer with Chromas Lite 2.01. CLC DNA Workbench software was used for editing, aligning and assembling of forward, reverse and internal sequences. BlastN was used to check the harmony sequences against GenBank. Extreme homology of the query sequences to the database sequences was determined.

\section{Results}

\section{Isolation of bacteria}

Total 30 bacterial strains were isolated from samples of soil contaminated with petroleum and its products. Ten out of thirty strains showed the biosurfactant activity.

\section{Screening for biosurfactant production}

Ten selected biosurfactant producing strains were screened for biosurfactant production by numerous tests. All the strains were positive for blood agar hemolysis, oil spreading technique, drop collapse assay and CTAB blue agar (figure 1, table 1).

Table 1: Screening of bacterial strains for biosurfactants production

\begin{tabular}{lcccc}
\hline Bacterial & $\begin{array}{l}\text { Blood } \\
\text { Strain }\end{array}$ & $\begin{array}{l}\text { Oil } \\
\text { Hemolysis }\end{array}$ & $\begin{array}{l}\text { Dpreading } \\
\text { Collapse }\end{array}$ & CTAB \\
\hline SF-1 & + & + & + & + \\
SF-2 & + & + & + & + \\
SF-3 & + & + & + & + \\
SF-4 & + & + & + & + \\
SM-1 & + & + & + & + \\
SM-2 & + & + & + & + \\
SM-3 & + & + & + & + \\
SW-1 & + & + & + & + \\
SW-2 & + & + & + & + \\
SW-3 & + & + & + & + \\
\hline Morphological & and & Biochemical \\
characterization & & &
\end{tabular}

Selected strains exhibited different colony morphology with pigments, texture and elevations. Majority of biosurfactant producing strains were Gram negative like, Acintetobacter SF-3, SM-3 Enterobacter- SF-4, Pseudomonas SF-1, SM-1, SW-1, SW-2, whereas two strains, SF-2 and SM-2 were Gram positives. Catalase was positive for all the strains except SF-2 and SM-2. Oxidase was negative for SF-2, SF-3, SF-4, SM-2 and SM-3 whereas results of sugar fermentation were exactly opposite to oxidase. Citrate was negative for SF-2 and SM-2. Nitrate reduction was negative for SF-3, SF-4, SM-2 and SM-3 whereas Indol was positive for SF-2 and SM-2.

\section{Optimization of growth parameters for the production of biosurfactants}

Glucose was best carbon source and yeast extract was best nitrogen source to enhance the growth of strains as shown in figure 2 and 3, respectively. Sucrose is second best carbon source; fructose gave transitional growth while glycerol reduced the growth. Beef extract and potassium nitrate overall reduced growth. Temperature $37^{\circ} \mathrm{C}$ and $\mathrm{pH} 7$ was the best condition for all strains as shown in figure 4 and 5 .

\section{Emulsification index of Biosurfactants in different oils}

It was found that Gangrene oil showed a high emulsification index, Kerosene oil and olive oil showed 
partial while cooking oil and coconut oil show low emulsification index (Table 2).

\section{Antibiotic and metal resistance profiling}

Most of the strains showed multiple antibiotic resistances. They were also resistant to different metals at variable concentrations. SF-1, SF-4, SM-1 were resistant to Streptomycin up to $500 \mu \mathrm{g} \mathrm{ml}^{-1}$ and

\section{FT-IR}

TWEEN-80 is a biosurfactant which was taken as a control. It showed strong absorption bands which are compared with our biosurfactant producing strains (Figure $6 \mathrm{~A}$ ). The absorption bands at $3132 \mathrm{~cm}^{-1}$ is due to $\mathrm{O}-\mathrm{H}$ stretching, Carbonyl group stretching which is the characteristic of ester compound was found at 1720
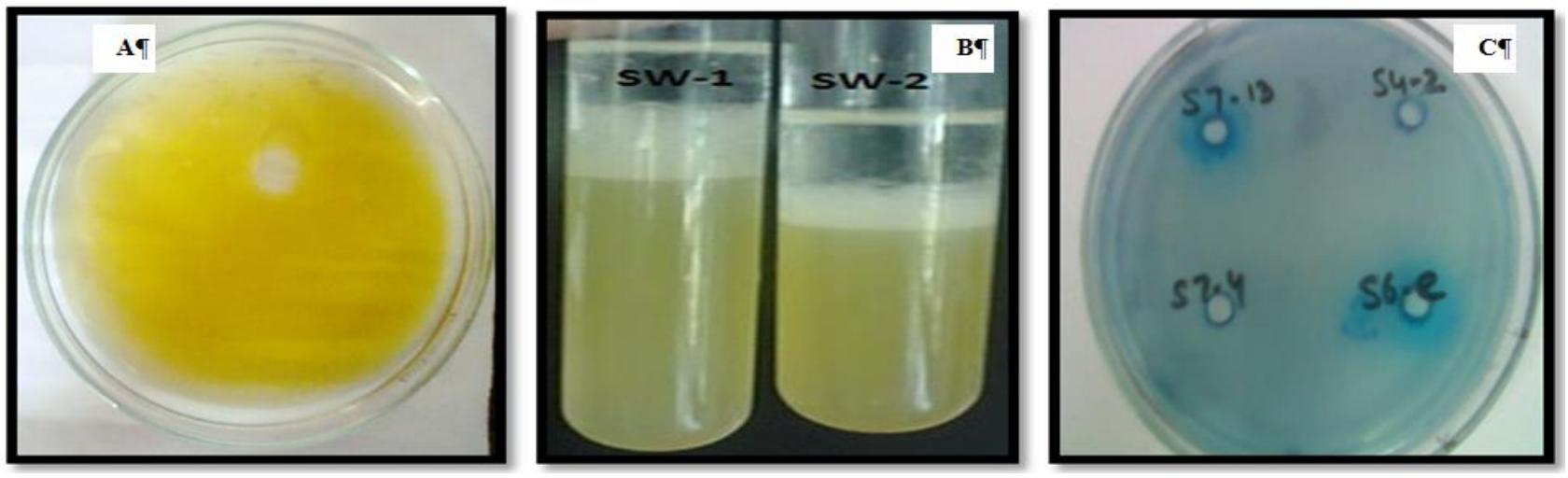

Figure 1: Biosurfactant activity of isolated bacterial strains A Oil spreading technique B Emulsification index C) CTAB Blue agar plate method

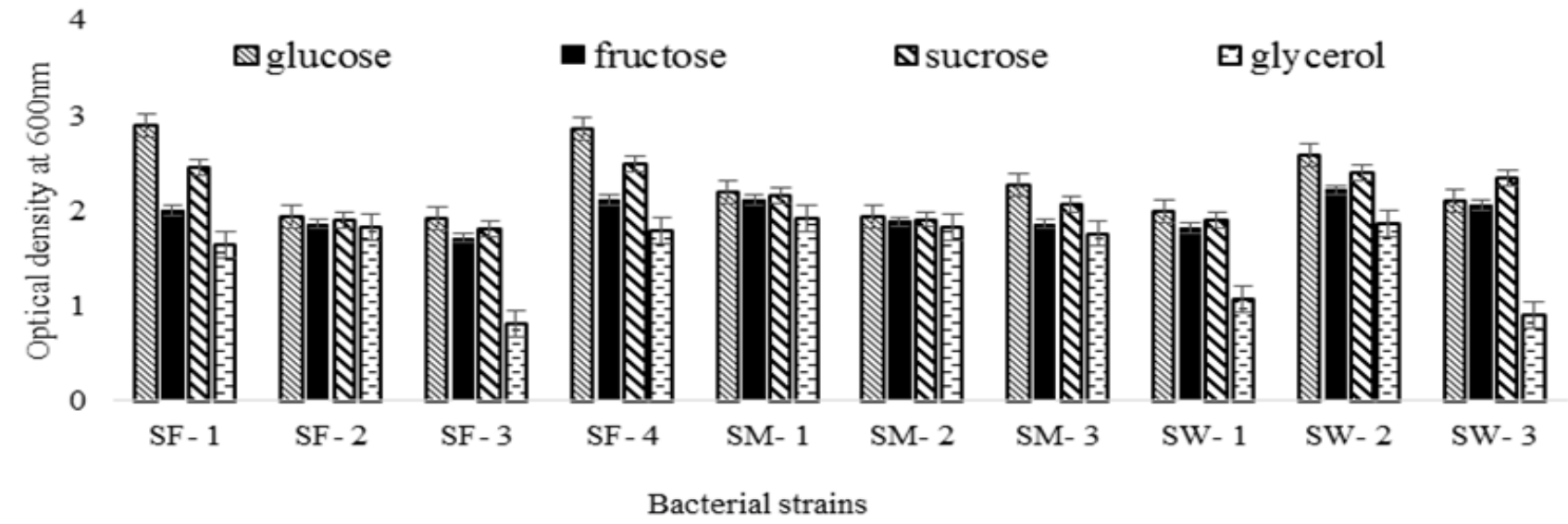

Figure 2: Production of biosurfactants by isolated bacterial strains with different carbon sources

Ampicillin up to $300 \mu \mathrm{g} \mathrm{ml}^{-1}$. Their resistance to selected heavy metals was up to $800-1000 \mu \mathrm{g} \mathrm{ml}^{-1}$ as shown in table 3 .

\section{Extraction and purification of biosurfactants}

In order to examine the chemical nature of honey colored residues obtained by solvent extraction, TLC was done. Yellow brown colored spots on TLC in iodine fumes indicated that biosurfactant produced by the isolates was lipid in nature. $R_{f}$ value of biosurfactant produced by our strains was 0.61-0.64 which is similar to standard rhamnose

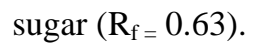

$\mathrm{cm}^{-1}$. Absorption bands at $1300 \mathrm{~cm}^{-1}$ indicates the structure identical to rhamnolipid. Strong adsorption peak at $2,920 \mathrm{~cm}^{-1}$ is anticipated to be the $\mathrm{C}-\mathrm{H}$ stretching vibrations of the hydrocarbon chain positions. Due to the stretching vibrations of $\mathrm{C}-\mathrm{H}$ of hydrocarbon chain position robust absorbance was seen at $1720 \mathrm{~cm}^{-1}$. Though, absorption peaks in the range of 1,300-1,100 $\mathrm{cm}^{-1}$ indicated that chemical structure was identical to rhamnolipid.

The important absorption bands located at 1738 and $2929 \mathrm{~cm}^{-1}$ which indicated that it had similarity with rhamnolipid. The presence of ester bond due to $\mathrm{C}=\mathrm{O}$ 
stretching is located at $1738 \mathrm{~cm}^{-1}$. Absorption peaks at $2929 \mathrm{~cm}^{-1}$ showed the stretching vibrations of hydrocarbon chains. Absorbance in the range of $1,300-1,100 \mathrm{~cm}^{-1}$ showed the occurrence of bands between carbon atoms and hydroxyl groups in the chemical structures of rhamnose rings. The absorption peak at $3139 \mathrm{~cm}^{-1}$ indicated the presence of hydroxyl groups (Figure $6 \mathrm{~B}, 6 \mathrm{C}$ and $6 \mathrm{D}$ ).

\section{SrRNA sequencing of biosurfactant producing strains}

The two best bacterial isolates among all biosurfactant producers were selected for 16SrRNA sequencing. These strains were SF-4 and SM-1. The 16SrRNA gene sequences with those in the NCBI sequence database (GenBank) were compared through BLAST (http://www.nlm.nih.gov/

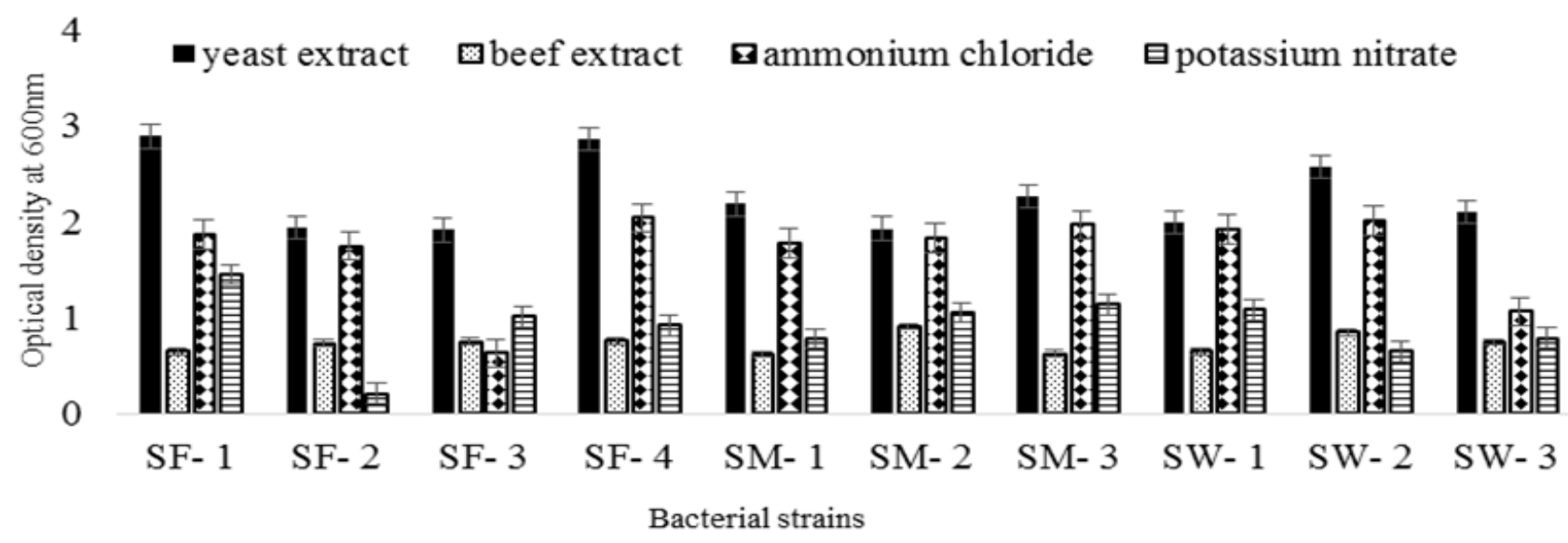

Figure 3: Production of biosurfactants by isolated bacterial strains with different nitrogen sources

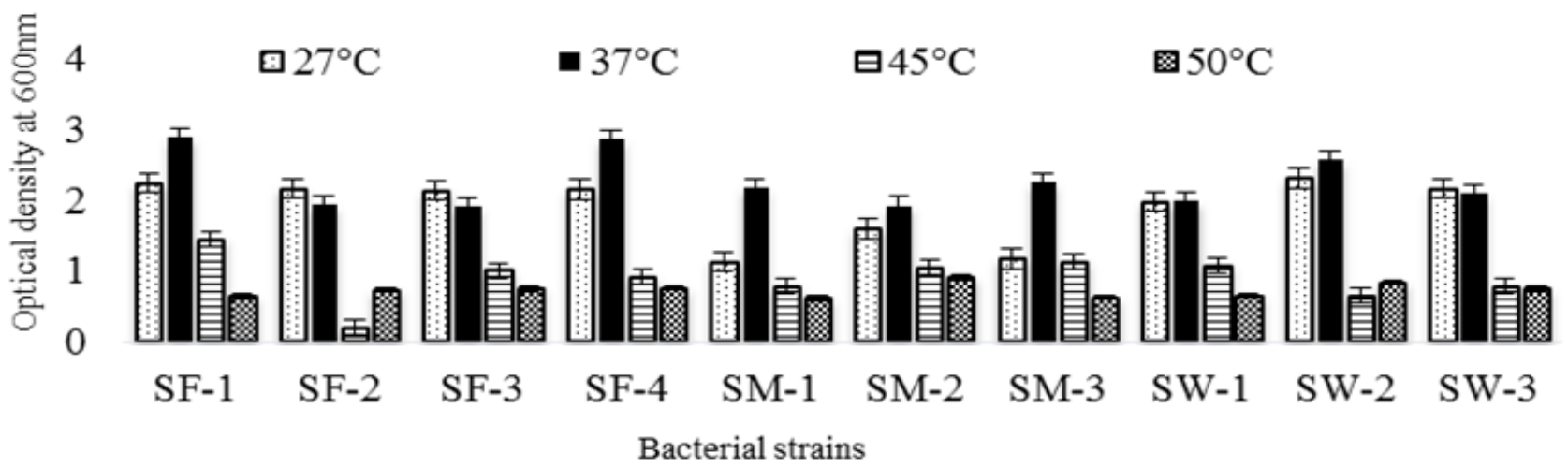

Figure 4: Production of biosurfactants by isolated bacterial strains at different growth temperature

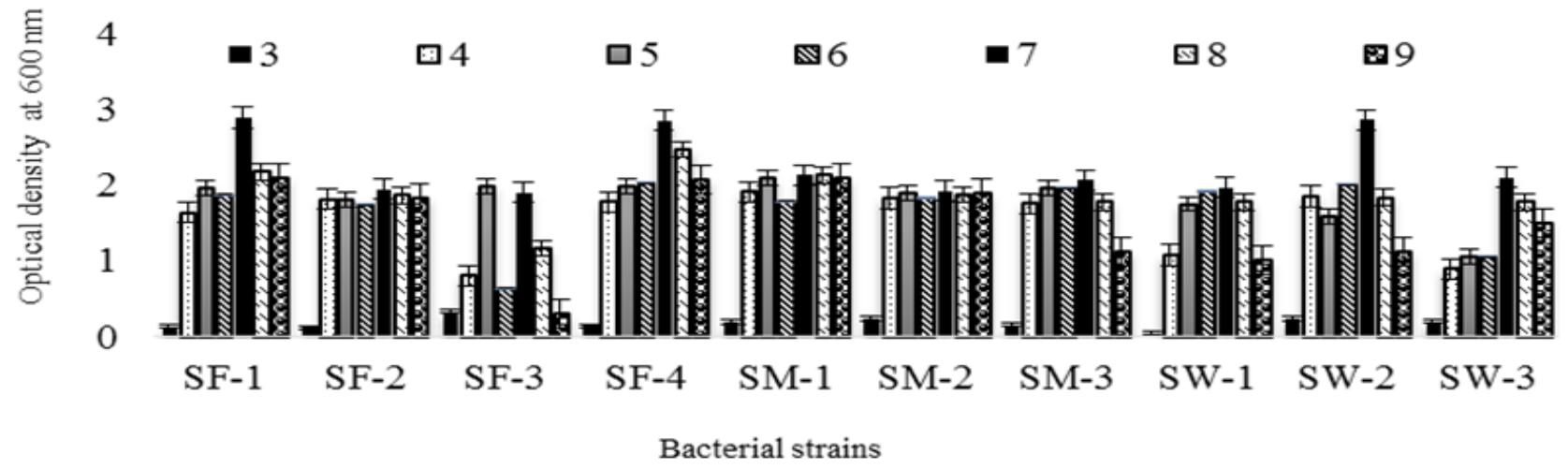

Figure 5: Production of biosurfactants by isolated bacterial strains at different $\mathrm{pH}$ 
Table 2: Emulsification index (\%) of isolated biosurfactant producing bacteria with different oils

\begin{tabular}{cccccc}
\hline Bacterial Strains & Gangrene Oil & Kerosene Oil & Coconut Oil & Cooking Oil & Olive Oil \\
\hline SF-1 & 50 & 27 & 27 & 34 & 40 \\
SF-2 & 16 & 11 & 20 & 10 & 16 \\
SF-3 & 13 & 16 & 20 & 10 & 22 \\
SF-4 & 34 & 20 & 20 & 40 & 30 \\
SM-1 & 53 & 28 & 30 & 37 & 27 \\
SM-2 & 50 & 40 & 34 & 50 & 43 \\
SM-3 & 30 & 34 & 37 & 43 & 43 \\
SW-1 & 20 & 25 & 16 & 16 & 20 \\
SW-2 & 32 & 30 & 30 & 20 & 25 \\
SW-3 & 30 & 28 & 31 & 22 & 30 \\
\hline
\end{tabular}

Table 3: Heavy metal resistance profiling of isolated biosurfactant producing bacteria

\begin{tabular}{|c|c|c|c|c|c|}
\hline \multirow{2}{*}{ Bacterial Strain } & \multicolumn{5}{|c|}{ Heavy Metals $\left(\mu \mathrm{g} \mathrm{ml}^{-1}\right)$} \\
\hline & $\mathrm{CdCl}_{2}$ & $\mathrm{ZnSO}_{4}$ & $\mathrm{CoCl}_{2}$ & $\mathrm{CoNO}_{3}$ & $\mathrm{CuSO}_{4}$ \\
\hline SF-1 & +1000 & +800 & +900 & +800 & +1000 \\
\hline SF-2 & +600 & +600 & +600 & +600 & +600 \\
\hline SF-3 & +600 & +600 & +600 & +600 & +600 \\
\hline SF-4 & +900 & +800 & +800 & +700 & +700 \\
\hline SM-1 & +900 & +1000 & +800 & +800 & +800 \\
\hline SM-2 & +600 & +600 & +600 & +700 & +600 \\
\hline SM-3 & +600 & +600 & +700 & +700 & +600 \\
\hline SW-1 & +600 & +600 & +700 & +700 & +700 \\
\hline SW-2 & +700 & +700 & +700 & +700 & +700 \\
\hline SW-3 & +700 & +700 & +700 & +700 & +700 \\
\hline
\end{tabular}

+ indicates growth up to...

BLAST). 16SrRNA gene sequence of the strain SM-1 was most closely related to Pseudomonas sp. while SF-4 showed homology with Enterobacter sp. (Figure 7 A, B). Sequences obtained were submitted to Genbank under the accession number KP794925 (Enterobacter cloacae strain SF-4) and KP794924 (Pseudomonas aeruginosa strain SM-1).

\section{Discussion}

The current study is aimed on the isolation of biosurfactant producing bacteria from hydrocarbon polluted soil. According to several published studies, investigators reported the successful isolation of biosurfactant producing organisms from soil polluted with hydrocarbons or mineral oils (Mukherjee et al., 2009; Mulligan, 2005). In this study ten biosurfactant producing strains were isolated form petroleum contaminated soil. Hemolytic activity seems to be a good selection measure in the exploration for biosurfactant producing bacteria.

Biosurfactants producing strains hemolysed the red blood cells and showed $\alpha$ or $\beta$ hemolysis. In present study, selected strains exhibited hemolytic activity which is principal screening technique for biosurfactant producing bacteria. Other methods such as oil spreading technique, drop collapse assay, emulsification index need to be carried out for further confirmation (Shoeb et al., 2015). The drop from supernatant of all the isolated strains collapsed and control remained in beaded form. Diameter of a sample and concentrations of biosurfactant in a drop have a direct relationship and if the drop having no biosurfactant remains in beaded form due to the hydrophobicity of oily surface that cause aggregation of droplets (Bodour and MillerMaier, 1998). Selected strains also showed oil displacement activity which was confirmed by oil spreading technique (Patil et al., 2012). Emulsification activity of all isolated strains was checked; all of them formed very stable emulsions. The cells developed a strong hydrophobic character during exponential phase and it may lose when cell enters into a stationary phase. Emulsification reduced oil drop size less than $1 \mu \mathrm{m}$ (Bredholt et al., 2002). CTAB blue agar plate assay is good for screening of new anionic biosurfactant production strains or mutants (Perfumo et al., 2006). Three biosurfactant producing strains, including SF- 
1, SF-4 and SM-1 produced blue haloes around their wells. The size of halo depends on rhamnolipids production (Siegmund and Wagner, 1991).

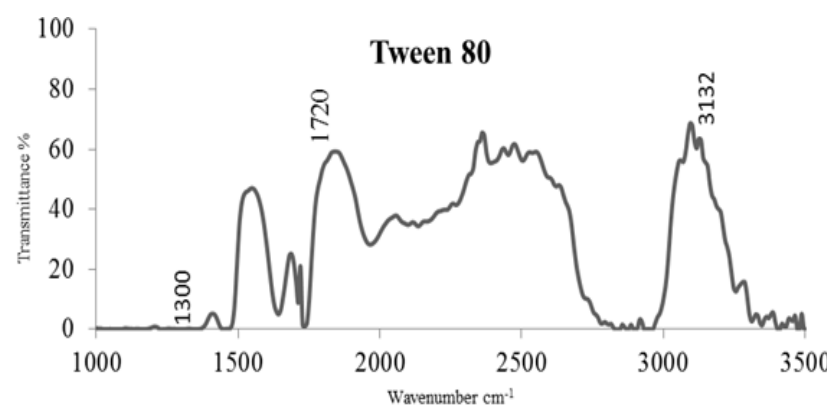

Figure 6 A: FT-IR spectrum of Tween 80

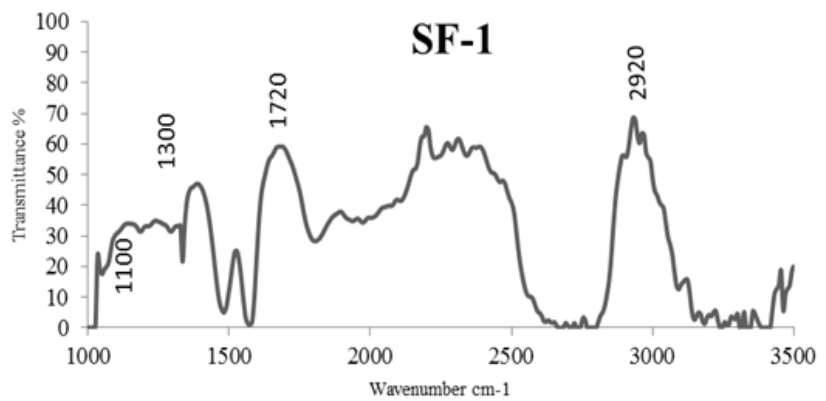

Figure 6 B: FT-IR spectrum of purified biosurfactant producing strain SF-1

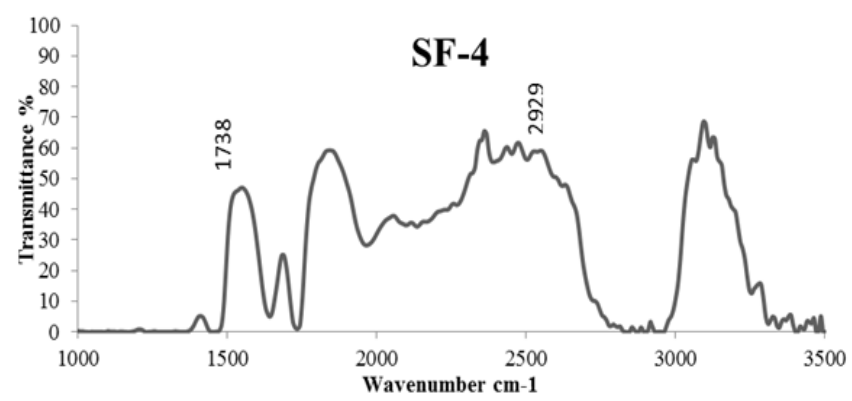

Figure 6 C: FT-IR spectrum of purified biosurfactant producing strain SF-4

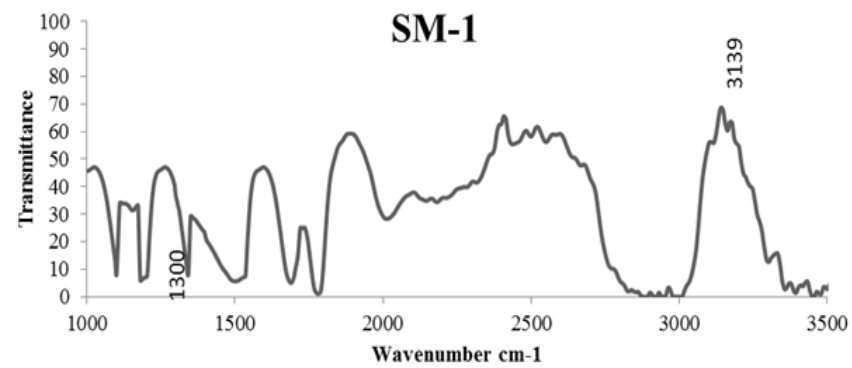

Figure 6 D: FT-IR spectrum of purified biosurfactant producing strain SM-1
Biosurfactants production is greatly influenced by the environmental factors and growth conditions such as $\mathrm{pH}$, temperature, carbon sources and nitrogen sources by influencing the cellular growth or activity. Similar findings were reported by Kim et al. (1997). It is described that biosurfactant producing bacteria showed maximum growth by using glucose and yeast extract (Khopade et al., 2012). Beef extract and potassium nitrate overall reduced microbial growth (Hamzah 2013). Maximum growth of biosufactants producing bacteria was at temperature $37^{\circ} \mathrm{C}$ and at $\mathrm{pH}$ 7. It is in accordance with the findings of previously published reports (Guerra-Santos et al., 1986; Hamzah 2013 ). In order to determine the potential of biosurfactants, emulsification activity estimation is one of the principle methods. Emulsifying activities (E24) regulate the yield of bioemulsifier (Shoeb et al., 2015). The most potent oil biodegrading strain in current research was Pseudomonas showed highest emulsification index (Shoeb et al., 2015).

It was found that Gangrene oil showed a high emulsification index, Kerosene oil and olive oil also exhibited good response (Abouseoud et al., 2007; Chander et al., 2012). Many of the strains showed multiple antibiotic resistances. Bacterial strains sequestered from contaminated sites were 40-200 times more resistant to heavy metals than related strains isolated from unpolluted sites (Bopp et al., 1983). It was found that the heavy metals were found among hydrocarbons and their presence produces a difficulty in biodegradation. So as a result, the microorganisms isolated from hydrocarbon contaminated sites show less sensitivity to metals prevailing on the site, such as quicksilver, copper and chromium (Fredrickson et al., 1995). Stress resistance in isolates has evidently shown the presence of pollutants at the sampling place (Shoeb et al., 2015). Thin layer chromatography (TLC) is a simple technique, used to purify the products in small quantities (Symmank et al., 2002). The biosurfactant produced by the isolates was lipid in nature as it produced yellow brown colored spots in iodine fumes with $R_{f}$ value of $(0.61)$ identical to standard rhamnose sugar $\left(\mathrm{R}_{\mathrm{f}}=0.63\right)$ (Stahl, 1969, Vyas and Dave, 2011). Most of researchers reported Pseudomonas as an efficient producer of rhamnolipid biosurfactant (Vyas and Dave, 2011). In FT-IR spectrum of partially purified biosurfactants produced by SF-1, SF-4 \& SM-1 further confirmed the presence of a rhamnolipid structure. The adsorption bands found are in accordance with the findings of Guo et al. (2009) presenting the existence of rhamnose rings and long hydrocarbon chains (Moussa et al., 2014). Most of the bacteria that are reported as hydrocarbon degraders belong to Pseudomonas (Widada et al., 2002). In the present study, bacterial strain SM-1 showed homology to Pseudomonas aeruginosa whereas 

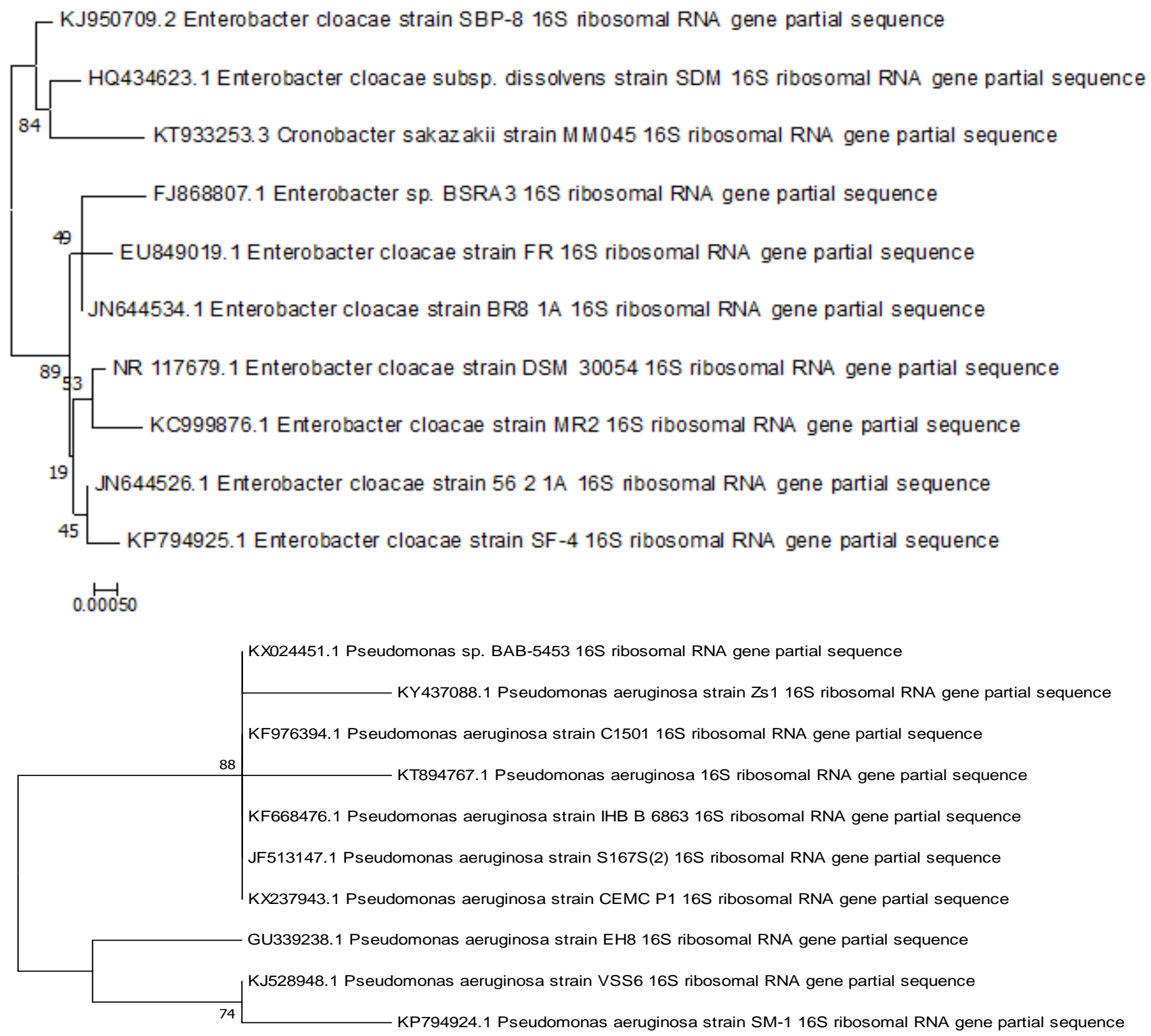

$\vdash_{0.00020}$

Figure 7: The evolutionary history was inferred using the Neighbor-Joining method (Saitou and Nei, 1987). Evolutionary analyses were conducted in MEGA7 (Kumar et al., 2106). A: Strain SF-4; B: Strain SM-1

bacterial strain (SF-4) showed belonging to Enterobacter cloacae. Production of biosurfactant by Enterobacter cloacae LK5 isolated from oil contaminated soil has reported previously (Sarin and Sarin, 2008).

\section{Future prospective}

Future of biosurfactants will depend on their production cost and applications. Biosurfactants can be used in environmental biotechnologies due to their low toxicity and biodegradability but their high production cost is major hindrance in the commercial success of biosurfactants. They may be helpful in the bioremediation of petroleum and lubricant contaminated sites.

\section{Acknowledgement}

University of the Punjab, Lahore, Pakistan is acknowledged for financial assistance. 


\section{References}

Abouseoud M., R. Maachi and A. Amrane. 2007 Biosurfactant Production from olive oil by Pseudomonas fluorescens. Communicating Current Research and Educational Topics and Trends in Applied Microbiology A. Méndez-Vilas (Ed.) 340-347. Formatex.

Ahmed, Z., M. Arshad, H.N. Asghar, M.A. Sheikh and D.E. Crowley. 2016. Isolation, screening and functional characterization of biosurfactant producing bacteria isolated from crude oil contaminated site. International Journal of Agriculture \& Biology 18:542-548.

Batista, S.B., A.H. Mounteer, F.R. Amorim and M.R. Totola. 2006. Isolation and characterization of biosurfactant/bioemulsifier-producing bacteria from petroleum contaminated sites. Bioresource Technology 97(6): 868-875.

Bicca, F.C., L.C. Fleck, and M.A. Zachio. 1999. Production of biosurfactant by hydrocarbon degrading Rhodococcus rubber and Rhodococcus erythropolis. Revista de Microbiologia 30(3);231-236.

Bodour, AA, R.M. Miller-Maier. 1998. Application of a modified drop-collapse technique for surfactant quantification and screening of biosurfactant producing microorganisms. Journal of Microbiological Methods 32(3):273-280.

Bopp, L.H., Chakrabarty, A.M. and H.L. Ehrlich. (1983). Chromate resistance plasmid in Pseudomonas fluorescens. Journal of Bacteriology 155(3):1105-1109.

Bredholt, H., P. Bruheim, M. Potocky, K. Eimhjellen. (2002). Hydrophobicity development, alkane oxidation and crude oil emulsification in Rhodococcus species. Canadian Journal of Microbiology 48(4):295-304.

Budsabun, T. 2015. Isolation of biosurfactant producing bacteria from petroleum contaminated terrestrial samples that collected in Bangkok, Thailand. ProcediaSocial and Behavioral Sciences 197: 1363-1366.

Cameotra, S.S and R.S. Makkar. 2004. Recent applications of biosurfactants as biological and immunological molecules. Current opinion in Microbiology 7(3):2626.

Cappuccino, J.G. and N. Sherman. 2002. Microbiology: A Laboratory Manual. $6^{\text {th }}$ Edition, Pearson Education Inc., San Francisco.

Chander, C.R.S., T. Lohitnath, Kumar, D.J.M. and P.K. Kalaichelvan. 2012. Production and characterization of biosurfactant from Bacillus subtilis MTCC441 and its evaluation to use as bioemulsifier for food biopreservative. Advances in Applied Science Research 3(3):1827-1831.
Copper, D.G. and Goldenberg, B.G. 1987. Surface-active agents from two Bacillus species. Applied and Environmental Microbiology 53(2):224-229.

Das, P., S. Mukherjee and R. Sen. 2009. Biosurfactant of marine origin exhibiting heavy metal remediation properties. Bioresource Technology 100(20): 48874890.

El-Sheshtawy, H.S., I. Aiad, M.E. Osman, A.A. AboELnasr, and A.S. Kobisy. 2015. Production of biosurfactant from Bacillus licheniformis for microbial enhanced oil recovery and inhibition the growth of sulfate reducing bacteria. Egyptian Journal of Petroleum 24(2): 155-162.

Fredrickson, J.K., D.L. Balkwill, G.R. Drake, M.F. Romine, D.B. Ringelberg and D.C. White. 1995. Aromaticdegrading Sphingomonas isolates from the deep subsurface. Applied and Environmental Microbiology 61:1917-1922.

Guerra-Santos. L.H., O. Käppeli and A. Fiechter. 1986. Dependence of Pseudomonas aeruginosa continous culture biosurfactant production on nutritional and environmental factors. Applied Microbiology and Biotechnology 24:443-448.

Guo, Y.P., Y.Y. Hu. R.R. Gu. and H. Lin. 2009. Characterization and micellization of rhamnolipidic fractions and crude extracts produced by Pseudomonas aeruginosa mutant MIG-N146. Journal of Colloid Interface Science 331(2): 356-363.

Hamzah, A., N. Sabturani. and S. Radiman 2013. Screening and optimization of biosurfactant production by the hydrocarbon-degrading bacteria. Sains Malaysiana 42: 615-623.

Hassanshahian, M. 2014. Isolation and characterization of biosurfactant producing bacteria from Persian Gulf (Bushehr provenance). Marine Pollution Bulletin 86(1): 361-366.

Khopade A., B. Ren. X.Y. Liu. K. Mahadik. L. Zhang and C. Kokare .2012. Production and characterization of biosurfactant from marine Streptomyces species B3. Journal of Colloid and Interface Science 367:311-318.

Kim H.S., B. Young. C.H. Lee. 1997. Production and properties of a lipopeptide biosurfactants from Bacillus subtilis C9. Journal of Fermentation and Bioengineering 84(11): 41-46.

Kumar S, G, Stecher and K. Tamura 2016. MEGA7 Molecular Evoluotionary Genetics Analysis version 7.0 for bigger datasets. Molecular Biology and Evolution 33: $1870-1874$.

Maier, R.M. 2003. Biosurfactants: evolution and diversity in bacteria. Advances in Applied Microbiology 52: 101-21.

Meybodi, S.M., J.M. Ghayyomi, S.A. Akhavan, F. Forghani, and M.R. Kouchaki. 2013. Isolation of biosurfactant producing bacteria from petroleum 
contaminated soils of the Sirri Island. Petroleum Research 22(72): 110-119.

Moussa, T.A., M.S. Mohamed, and N. Samak. 2014. Production and characterization of di-rhamnolipid produced by Pseudomonas aeruginosa TMN. Brazilian Journal of Chemical Engineering 31(4): 867-880.

Mukherjee S., P. Das, and R. Sen. 2009. Rapid quantification of a microbial surfactant by a simple turbidometric method. Journal of Microbial Method 76: $38-42$.

Mulligan, C.N. 2005. Environmental applications for biosurfactants. Environmental pollution 133:183-198.

Ongena, M. and P. Jacques. 2008. Bacillus lipopeptides: versatile weapons for plant disease biocontrol. Trends in Microbiology 16(3): 115-125.

Patil. S. B. Aglave. A. Pethkar. And V. Gaikwad. 2012. Stenotrophomonas koreensis a novel biosurfactant producer for abatement of heavy metals from the environment. African Journal of Microbiology Research 6:5173-5178.

Perfumo, A. I.M. Banat. F. Canganella. and R. Marchant. 2006. Rhamnolipid production by a novel thermophilic hydrocarbon-degrading Pseudomonas aeruginosa AP02-1. Applied Microbial and Cell Physiology 72:132-138.

Rodrigues, L., I.M. Banat. J. Teixeira and R. Oliveira 2006. Biosurfactants: potential applications in medicine. Journal of Antimicrobial Chemotherapy 57(4): 609618.

Ron, E.Z, and E. Rosenberg. 2001. Natural roles of biosurfactants. Environmental Microbiology 3(4): 229236.

Saitou, N. and M. Nei. 1987. The neighbor-joining method: A new method for reconstructing phylogenetic trees. Molecular Biology and Evolution 4:406-425.

Sandrin, T.R., A.M. Chech and R.M. Maier. 2000. A rhamnolipid biosurfactant reduces cadmium toxicity during naphthalene biodegradation. Appl. Environ. Microbiol. 66(10):4585-4588.
Sarin, S. and C. Sarin. 2013. Production, isolation and application of biosurfactant/bioemulsifier by oil contaminated soil isolate Enterobacter cloacae LK5. Naresuan University Journal 16(2): 113-125.

Sen, R. 2008. Biotechnology in petroleum recovery: the microbial EOR. Progress in Energy and Combustion Science 34:714-724.

Shoeb E. N. Ahmed. J. Akhter. U. Badar. K. Siddiqui. K.F.Ansari, et al. 2015. Screening and characterization of biosurfactant-producing bacteria isolated from the Arabian Sea coast of Karachi. Turkish Journal of Biology 39: 210-216.

Siegmund, I. and F. Wagner. 1991. New method for detecting rhamnolipids excreted by Pseudomonas species during growth on mineral agar. Biotechnology Techniques 5:265-268.

Stahl. E. 1969. Thin-Layer Chromatography. Springer Verlag, New York.

Symmank, H. P. Franke. W. Saenger, and F. Bernhard. 2002 Modification of biologically active peptides: production of a novel lipohexapeptide after engineering of Bacillus subtilis surfactin synthetase. Protein Engineering 15:913-921.

Vyas T. and B. Dave. 2011. Production of biosurfactant by Nocardia otitidiscaviarum and its role in biodegradation of crude oil. International Journal of Environmental Science and Technology 8:425-432.

Widada, J. H. Nojiri. K. Kasuga T. Yoshida H. Habe and T. Omori. 2002. Molecular detection and diversity of polycyclic aromatic hydrocarbon-degrading bacteria isolated from geographically diverse sites. Applied Microbiology and Biotechnology 58(2): 202-209. 